\title{
Bentuk Pertanggungjawaban Pidana Korporasi Sebagai Pelaku Tindak Pidana Dumping Limbah Bahan Berbahaya dan Beracun ke Media Lingkungan Hidup*
}

\author{
Anton Wahyudi, ${ }^{1}$ Tofik Yanuar Chandra ${ }^{2}$ \\ Universitas Jayabaya Jakarta \\ d. \\ $10.15408 / j \mid r . v 3 i 4.22004$
}

\begin{abstract}
Protection of the environment is a must both for humans themselves. A corporation is a form of business entity which is run by humans to achieve their interests and gain profits. Environment and humans are 2 objects that are very dependent on each other. The integration between humans and the environment on the sustainability of human life itself, will affect various aspects of the Corporation in carrying out its business activities, so that it will affect the environmental system. Thus, the environment will certainly affect human life itself. One of the potentials in this crime is the crime of dumping hazardous waste, which in the nature of Law Number 32 of 2009 concerning Environmental Protection and Management, dumping of hazardous waste is prohibited if it is not managed. Protection of the environment is a must both for humans themselves. A corporation is a form of business entity which is run by humans to achieve their interests and gain profits.
\end{abstract}

Keywords: Crime; Waste Dumping; Corporation

* Received: 20 May 2021, Revision: 06 June 2021, Publish: 15 July 2021.

1 Anton Wahyudi adalah Mahasiswa Magister Ilmu Hukum di Universitas Jayabaya. Email: Anton200584@gmail.com

2 Tofik Yanuar Chandra adalah Dosen Ilmu Hukum di Universitas Jayabaya., email: tyc.jayabaya@gmail.com 


\section{A. PENDAHULUAN}

Di era modern ini, globalisasi ekonomi merupakan hal yang mutlak terjadi dan tak dapat dihindari. Kondisi ini meningkatkan persaingan bisnis yang semakin ketat. Untuk meningkatkan investasi dan mendorong produksi, Negara pun perlu melakukan perbaikan dan inovasi dalam berbagai sektor ekonomi. Bagi sektor bisnis, perdagangan, manufaktur, maupun pembangunan, impor atau proses transportasi barang maupun komoditas dari negara lain merupakan aktivitas yang lazim dan penting.

Menurut Asas territorial, berlakunya undang-undang pidana suatu negara digantungkan pada tempat dimana tindak pidana atau perbuatan dilakukan, dan tempat tersebut harus terletak di dalm teritori atau wilayah negara yang bersangkutan.

Lingkungan dan manusia adalah 2 objek yang sangat bergantung satu sama lain. Aktivitas manusia akan mempengaruhi lingkungan, sehingga manusia dan lingkungan mempunyai hubungan timbal balik. ${ }^{3}$ Sementara itu, antara Korporasi dan lingkungan ruang lingkupnya sangatlah berkaitan. Integrasi antara manusia dan lingkungan terhadap keberlangsungan kehidupan manusia itu sendiri, akan mempengaruhi berbagai aspek-aspek Korporasi dalam menjalankan kegiatan usahanya, sehingga akan mempengaruhi sistem lingkungan. Dengan demikian, lingkungan tentunya akan mempengaruhi kehidupan manusia itu sendiri.

Lingkungan hidup yang sehat adalah merupakan hak dari setiap manusia dan makhluk hidup lainnya yang ada di dalam lingkungan hidup itu. Hal ini tercermin di dalam Undang-Undang pengelolaan dan perlindungan lingkungan hidup. Lingkungan hidup yang sehat dapat diartikan sebagai lingkungan yang dapat terjaga keseimbangannya, dimana keseimbangan itu dijaga oleh manusia sebagai komponen utama dalam melakukan pengelolaan lingkungan hidup. Media lingkungan merupakan tempat tinggal dan tempat berlangsungnya kehidupan komponen-komponen makhluk hidup dalam suatu ekosistem. Di dalam lingkungan hidup yang baik, interaksi antara berbagai komponen akan terdapat keseimbangan. ${ }^{4}$

3 M. Daud Silalahi, Hukum Lingkungan dalam Sistem Penegakan Hukum Lingkungan Indonesia, Alumni, Bandung, 2001, hlm. 9

${ }^{4}$ N.H.T. Siahaan, Hukum lingkungan dan Ekologi Pembangunan, edisi kedua, Penerbit Erlangga, Jakarta, 2004, hlm. 25 
Pencemaran limbah pabrik yang masih murni ( Waste Water Treatment), lambat laun akan berdampak pada lingkungan. ${ }^{5}$ Demikian juga halnya dengan Limbah B3 (Bahan Berbahaya dan Beracun). Dumping Limbah B3 tanpa pengelolaan merupakan salah satu pencemaran lingkungan yang mengakibatkan perubahan terhadap fungsi-fungsi lingkungan yang normal. Perubahan terhadap lingkungan ini juga akan turut mempengaruhi perubahan daripada keberlangsungan hidup manusia. Kerugian-kerugian yang ditimbulkan akibat dari perubahan fisik ini dapat mencapai terhadap segala aspek, baik itu kesehatan, ekonomi, sosial dan lainnya. Sebagai respon terhadap masalah perubahan lingkungan, Negara Republik Indonesia sudah mengatur ketentuan mengenai Limbah B3 melalui Undang- Undang Nomor 32 Tahun 2009 tentang Pengelolaan dan Perlindungan Lingkungan Hidup.

Undang-Undang Nomor 32 Tahun 2009 yang mengatur tentang Perlindungan dan Pengelolaan Lingkungan Hidup mewajibkan setiap orang yang menghasilkan Limbah B3 wajib melakukan pengelolaan Limbah B3. Dalam hal perusahaan cabang, Pimpinan Perusahaan Cabang yang mana Perusahaannya itu menghasilkan Limbah B3 wajib melakukan pengelolaan Limbah B3. Pertanggungjawaban pidana terhadap korporasi dapat dilihat dari berbagai jenis. Pertanggungjawaban ini meliputi pertanggungjawaban terhadap Korporasi, Pimpinan Korporasi dan karyawannya.

Pemidanaan korporasi tentunya harus berdasarkan peraturan perundang-undangan yang berlaku. Kitab Undang-Undang Hukum Pidana (KUHP) sendiri belum mengenal tindak pidana yang dilakukan oleh korporasi. Namun di dalam Pasal 59 KUHP, terdapat sanksi pidana kepada Pengurus, anggota-anggota badan pengurus atau komisaris-komisaris dalam hal terjadi tindak pidana. Kemudian dalam perkembangannya peraturan perundangundangan memasukkan korporasi sebagai subjek hukum pidana. Dimasukkannya korporasi sebagai subjek hukum pidana adalah sebagai perwujudan perlindungan hukum bagi setiap warga Negara atas tindak pidana yang dilakukan oleh korporasi melalui karyawan atau pimpinan korporasinya.

Menurut Nomor 32 Tahun 2009 tentang Perlindungan dan Pengelolaan Lingkungan Hidup setiap orang yang menghasilkan Limbah B3 dan tidak melakukan pengelolaan dapat diberikan sanksi pidana. Adanya kesalahan adalah salah satu unsur dari pertanggungjawaban pidana. Kesalahan dapat ditentukan melalui ada atau tidaknya peraturan yang dilanggar oleh setiap

${ }^{5}$ P. Joko Subagyo., Hukum Lingkungan dan Masalah Penanggulannnya, Edisi Terbaru, Rineka Cipta, Jakarta, 1999, hlm. 27 
orang. Undang-undang dibuat oleh negara dan setiap orang dianggap mengetahuinya. Maka, setiap orang yang mampu memberi pertanggungjawaban pidana, tidak dapat menggunakan alasan bahwa ia tidak mengetahui akan adanya suatu peraturan dengan ancaman hukuman tentang perbuatan yang dilakukannya. ${ }^{6}$

Mengenai persoalan pertanggungjawaban pidana korporasi, Schaffmesiter menanyakan apabila suatu badan Hukum (korporasi) dituntut, bagaimanakan badan hukum yang tidak mempunyai jiwa manusia "menselijke Psychis" dapat memenuhi unsur psikis (de Psychische bestandelen) yaitu kesengajaan (opzet) dan kealpaan (culpa). ${ }^{7}$

Tentu dalam hal ini, meminta pertanggungjawaban pidana akan memiliki hambatan. Hambatan itu berasal dari persyaratan biasa hukum pidana, yang memegang seseorang yang bertanggung jawab atas pelaksanaan tindakan terlarang (actus reus) yang dilakukan bersamaan dengan sikap terdisiplin (mens rea). Sesuai dengan premis individu-orang, entitas harus memiliki satu pikiran alami untuk dikaitkan dengan sikap yang disengaja. ${ }^{8}$

Kejahatan korporasi merupakan salah satu bentuk dari kejahatan white collar. ${ }^{9}$ Sutherland mencoba mendiskripsikan aktifitas criminal yang dilakukan seseorang yang memiliki status sosial yang tinggi serta dihormati.yang orang tersebut menggunakan jabatan pekerjaannya sebagai sarana untuk melanggar hukum. ${ }^{10}$ Dalam pemahaman sistem common law bahwa korporasi tidak biasa dituntut pertanggung jawaban, namun perorangan dalam korporasi tersebut. Korporasi adalah benda mati maka dari itu tidak mungkin korporasi memiliki mens rea yang diperlukan untuk pertanggung jawaban. Lebih lanjut korporasi tidak memiliki atribusi fisik, sehingga elemen ectus reus pun tidak ada. Selain itu kalau dapat dijatuhi pidana, korporasi tidak bisa dipenjarakan atas tindak kejahatannya.

${ }^{6}$ CST. Kansil dan Christine Kansil., Pokok-Pokok Hukum Pidana, Pradnya Paramita, 2004, hlm. 49

7 Setiyono, Kejahatan Korporasi Analisis Viktimiologis dan Pertanggungjawaban Korporasi dalam Hukum Pidana Indonesia, Bayumedia Publishing, Malang, 2009, hal.109.

${ }^{8}$ William Robert Thomas, How And Why Should The Criminal Law Punish Corporation, Dissertation, University of Michigan, 2015

9 Marjono raksodipoetra, Kejahatan Korporasi dan Pertanggungjawabannya, Universitas Gadjah Mada, Yogyakarta, 2014, hlm. 8.

10 Selly S Simpon, Corporate Crime, Law and Social Control. Cambridge University Pers, London, 2002, hlm. 6. 
Dalam KUHP saat ini yang berlaku di Indonesia tidak dikenal adanya satu ketentuan pun yang menetapkan korporasi sebagai subyek delik dalam hukum pidana. Hal ini dikarenakan bahwa KUHP Belanda yang diberlakukan di Indonesia tidak mengenal pengenaan pidana kepada korporasi, sebab Code Napoleon yang menjadi pangkal ketentuan KUHP Belanda tidak mengenal subyek hukum pidana korporasi. KUHP hanya mengenal manusia secara alamiah sebagai subyek hukum pidana. ${ }^{11}$

\section{B. METODE PENELITIAN}

Penelitian ini memerlukan Hukum Positif yang berlaku di Indonesia, dan teori-teori yang berkaitan dengan pertanggungjawaban pidana Korporasi. Sehingga jenis Penelitian yang dilakukan dalam penelitian ini adalah penelitian hukum Normatif. Penelitian hukum Normatif ini dilakukan dengan cara meneliti bahan hukum primer dan sekunder. ${ }^{12}$ Penelitian ini menitik beratkan kepada masalah pertanggungjawaban pidana korporasi. Bahan hukum primer dan bahan hukum sekunder itu nantinya akan dikaitkan satu dengan yang lain dengan melihat sinkronisasinya. Penelitian Hukum Normatif akan melihat sinkronisasi suatu peraturan dengan peraturan lainnya secara hierarki. ${ }^{13}$

\section{HASIL TEMUAN DAN PEMBAHASAN}

\section{Dampak yang ditimbulkan akibat Tindak Pidana Dumping Limbah Bahan Berbahaya dan Beracun di lingkungan dan masyarakat}

Pertumbuhan dan perkembangan industri yang sangat pesat, mengakibatkan pencemaran dan kerusakan lingkungan sebagai akibat dari perilaku manusia melalui berbagai kegiatan yang menempatkan alam sebagai komoditas yang hanya diperlakukan sebagai objek eksploitasi, media pembuangan, dan kegiatan industri tanpa menghiraukan bahwa lingkungan itu materi yang mempunyai keterbatasan dan bisa mengalami kerusakan. ${ }^{14}$

${ }^{11}$ Hasbullah F. Sjawie, Pertanggungjawaban Pidana Korporasi pada Tindak Pidana Korupsi, Prenada Media Group, Jakarta, 2015, hlm 97

${ }^{12}$ Peter Mahmud Marzuki, Penelitian Hukum, Kencana Prenada Media Group, Jakarta, 2010, hlm. 142.

${ }^{13}$ Zainuddin Ali, Metode Penelitian Hukum, Sinar Grafika, Jakarta, 2009, hlm. 105.

14 Absori, Penegakan Hukum Lingkungan pada Era Reformasi, Jurnal Ilmu Hukum, Vol.8, No.2, September 2005, h. 221-237 
Masyarakat merupakan salah satu korban tindak pidana korporasi di bidang lingkungan hidup baik secara langsung maupun tidak langsung, khususnya masyarakat yang tinggal di sekitar industri, yang mengalami kerugian materi, gangguan kesehatan, maupun keselamatan. Menurut Geis, setiap tahunnya korporasi bertanggungjawab terhadap ribuan kematian dan cacat tubuh yang terjadi di seluruh dunia. Resiko kematian dan cacat yang disebabkan oleh korporasi dapat diakibatkan baik oleh produk yang dihasilkan oleh korporasi maupun dalam proses produksi.

Kerusakan dan pencemaran lingkungan dapat digolongkan kepada beberapa kelompok, yaitu: 1). Kronis, dalam keadaan ini kerusakan dan pencemaran lingkungan terjadi secara progresif tetapi prosesnya lambat; 2). Kejutan atau akut, dalam keadaan ini perusakan dan pencemaran lingkungan terjadi secara mendadak dan kondisinya sangat berat; 3). Berbahaya, terjadi kerugian biologis cukup berat, dan dalam hal ada radioaktivitas maka terjadi kerusakan genetis; 4). Katastrofis, di sini kematian organis hidup cukup banyak, organisme hidup menjadi punah sama sekali. ${ }^{15}$

Sutan Remy Sjahdeini menyatakan bahwa perlu diterapkannya konsep Pengurus dan korporasi keduanya sebagai pelaku tindak pidana dan keduanya pula yang harus memikul pertanggungjawaban pidana dalam tindak pidana korporasi, yang didasarkan hal-hal sebagai berikut:

a. Apabila hanya pengurus yang dibebani pertanggungjawaban pidana, maka menjadi tidak adil bagi masyarakat yang telah menderita kerugian karena pengurus dalam melakukan perbuatannya itu adalah untuk dan atas nama korporasi serta dimaksudkan untuk memberikan keuntungan atau menghindarkan mengurangi kerugian finansial bagi korporasi.

b. Apabila yang dibebani pertanggungjawaban pidana hanya korporasi sedangkan pengurus tidak harus memikul tanggung jawab, maka sistem ini akan dapat memungkinkan pengurus bersikap "lempar batu sembunyi tangan" atau mengalihkan pertanggungjawaban. Dengan kata lain, pengurus akan selalu dapat berlindung di balik punggung korporasi untuk melepaskan dirinya dari tanggung jawab dengan dalih bahwa perbuatannya itu bukan merupakan perbuatan pribadi dan bukan untuk kepentingan pribadi, tetapi merupakan perbuatan yang

15 Abdul Manan, 2015, Pencemaran dan Perusakan Lingkungan Dalam Perspektif Hukum Islam, Jurnal Hukum dan Peradilan, Vol. 4, No. 2, hlm. 228. 
dilakukannya untuk dan atas nama korporasi dan untuk kepentingan korporasi.

c. Pembebanan pertanggungjawaban pidana kepada korporasi hanya mungkin secara vikarius, atau bukan langsung (doctrine of vicrious liability), pertanggungjawaban atas tidak pidana yang dilakukan oleh seseorang dibebankan kepada pihak lain. Dalam hal pertanggungjawaban pidana, korporasi dialihkan pertanggungjawaban pidananya kepada korporasi. Pembebanan pertanggungjawaban pidana kepada korporasi hanya mungkin dilakukan secara vikarius karena korporasi tidak mungkin dapat melakukan sendiri suatu perbuatan hukum. Artinya, segala perbuatan hukum yang benar atau yang salah baik dalam lapangan keperdataan maupun yang diatur oleh ketentuan pidana, dilakukan oleh manusia yang menjalankan kepengurusan korporasi.

Dampak dari pencemaran limbah yang tidak dikelola dengan baik berupa pencemaran tanah, air dan udara, serta banjir. Beberapa hal dampak pencemaran dan perusakan lingkungan yaitu: 1). Kerugian ekonomi dan sosial (economic and social injury); 2). Gangguan sanitari (sanitary hazard); 3). Gangguan keseimbangan dalam kehidupan manusia, terutama menyangkut ekologi. ${ }^{16}$

Dalam Penjelasan Umum UU No. 32 Tahun 2009 tentang PPLH disebutkan bahwa dalam hal pencemaran dan kerusakan lingkungan hidup sudah terjadi, perlu dilakukan upaya represif berupa penegakan hukum yang efektif, konsekuen, dan konsisten terhadap pencemaran dan kerusakan lingkungan hidup yang sudah terjadi. ${ }^{17}$

Menurut ketentuan Pasal 59 Undang-Undang Nomor 32 Tahun 2009 tentang Perlindungan dan Pengelolaan Lingkungan Hidup bahwa:18 1) Setiap orang yang menghasilkan limbah B3 wajib melakukan pengelolaan limbah B3 yang dihasilkannya. 2) Dalam hal B3 sebagaimana dimaksud dalamn Pasal 58 ayat (1) telah kedaluwarsa, pengelolaannya mengikuti ketentuan pengelolaan limbah B3. 3) Dalam hal setiap orang tidak mampu melakukan sendiri pengelolaan limbah B3, pengelolaannya diserahkan kepada pihak lain. 4)

16 Rudy Hendra Pakpahan., Pertanggungjawaban Pidana Korporasi Perkebunan Atas Pencemaran Limbah Kelapa Sawit., Jurnal Legislasi Indonesia Vol 17 No. 2 - Juni $2020: 223-233$

17 UU No. 32 Tahun 2009 tentang PPLH

${ }^{18}$ Undang-Undang Nomor 32 Tahun 2009 tentang Perlindungan dan Pengelolaan Lingkungan Hidup 
Pengelolaan limbah B3 wajib mendapat izin dari Menteri, gubernur, atau bupati/walikota sesuai dengan kewenangannya. 5) Menteri, gubernur, atau bupati/walikota wajib mencantumkan persyaratan lingkungan hidup yang harus dipenuhi dan kewajiban yang harus dipatuhi pengelola limbah B3 dalam izin. 6) Keputusan pemberian izin wajib diumumkan. 7) Ketentuan lebih lanjut mengenai pengelolaan limbah B3 diatur dalam Peraturan Pemerintah.

Dampak kejahatan korporasi di bidang lingkungan hidup secara umum tidak hanya menguras sumber daya alam, tetapi juga modal manusia, modal sosial, bahkan modal kelembagaan yang berkelanjutan. Jadi kejahatan korporasi ini tidak akan selesai hanya dengan memberi penyantunan korban, akan tetapi dampaknya terhadap kerusakan lingkungan hidup akibat eksploitasi yang menguras sumberdaya alam tentunya membutuhkan waktu yang cukup lama untuk bisa kembali seperti semula, bahkan ada juga yang tidak bisa kembali lagi karena sifatnya.

\section{Penerapan Sanksi Pidana Korporasi Sebagai Pelaku Tindak Pidana Dumping Limbah Bahan Berbahaya Dan Beracun Ke Media Lingkungan Hidup.}

Peranan korporasi dalam perkembangan ekonomi masyarakat tersebut tidak hanya berdampak positif, tetapi juga menimbulkan dampak negatif, salah satunya adalah berkembangnya perilaku menyimpang yang dilakukan oleh korporasi yang bermotif ekonomi dimana karakteristik dan modus operandinya berbeda dengan kejahatan konvensional pada umumnya, sehingga penegakan hukumnya membutuhkan penanganan dengan instrumen khusus. Hal ini sejalan dengan apa yang tertuang di dalam Peraturan Mahkamah Agung Republik Indonesia Nomor 13 Tahun 2016 Tentang Tata Cara Penanganan Perkara Tindak Pidana oleh Korporasi yang menyatakan bahwa korporasi sebagai subjek hukum keberadaannya memberikan kontribusi yang besar dalam meningkatkan pertumbuhan ekonomi dan pembangunan nasional, namun dalam kenyataannya korporasi ada kalanya juga melakukan berbagai tindak pidana yang membawa dampak kerugian terhadap negara dan masyarakat. Terkait hal ini, Pasal 1 angka 1 Perma tersebut mengartikan korporasi sebagai "kumpulan orang dan/atau kekayaan yang terorganisir, baik merupakan badan hukum maupun bukan badan hukum."

Pengelolaan lingkungan hidup adalah upaya terpadu untuk melestarikan fungsi lingkungan hidup yang meliputi kebijaksanaan penataan, pemanfaatan, pengembangan, pemeliharaan, pemulihan, pengawasan, dan 
pengendalian lingkungan hidup. Arah dan pendekatan pengelolaan lingkungan hidup dilandasi oleh cara pandang (visi) yang luas dan tajam jauh kedepan dengan misi yang jelas dan program-program nyata yang bermanfaat dalam rangka mewujudkan suatu kebijaksanaan program pengelolaan lingkungan hidup dengan paradigma, mengintegrasikan tuntutan penerapan hak asasi, demokrasi dan lingkungan hidup dalam suatu kelestarian fungsi lingkungan yang menunjang ketahanan lingkungan. ${ }^{19}$

Pada praktek penegakan tindak pidana lingkungan hidup yang dilakukan oleh suatu korporasi atau badan usaha, pertanggungjawaban pidananya seringkali dikenakan pada pengurus perseroan, sedangkan perseroan tersebut justru jarang dimintai pertanggungjawaban pidana. Permasalahan selanjutnya ialah siapa yang dapat dipertanggungjawabkan, khususnya dalam arti siapakah yang dapat mempertanggungjawabkan dalam persidangan, atau siapa yang mewakili dipersidangan. Siapakah yang harus mempertanggungjawabkan dalam persidangan apabila suatu korporasi dituntut pidana.

Hal ini dapat dilihat untuk tindak pidana ekonomi dalam Pasal 15 ayat (3) UU No 7 Drt tahun 1955, yang berbunyi:20 "jika tuntutan pidana dilakukan terhadap suatu badan hukum, suatu perseroan, suatu perserikatan, orang atau yayasan, maka badan hukum, perseroan, perserikatan atau yayasan itu pada waktu penuntutan diwakili oleh seorang pengurus atau jika ada lebih dari seorang pengurus oleh salah seorang dari mereka itu. Wakil dapat diwakili oleh orang lain. Hakim dapat memerintahkan supaya seorang pengurus menghadap sendiri di pengadilan dan dapat pula memerintahkan supaya pengurus itu dibawa ke muka hakim."

Undang-Undang Nomor 32 Tahun 2009 tentang Perlindungan dan Pengelolaan Lingkungan Hidup (UU PPLH) disusun sebagai salah satu intrumen penegakan hukum tindak pidana korporasi di bidang lingkungan hidup. UU PPLH tersebut mengatur bahwa suatu korporasi atau badan usaha yang melakukan tindak pidana lingkungan hidup memiliki 3 (tiga) model pertanggungjawaban pidana dimana hal ini tertuang dalam Pasal 116 ayat (1) huruf a dan b, sebagai berikut:

19 Siswanto Sunarso, Hukum Pidana Lingkungan Hidup dan Strategi Penyelesaian Sengketa, Jakarta: Rineka Cipta, 2005, hlm 44

20 Muladi dan Dwidja Priyanto, Pertanggungjawaban Pidana Korporasi. Kencana Prenada Media Group, Jakarta, 2010, hlm 95. 
Pertama, Apabila tindak pidana lingkungan hidup dilakukan oleh, untuk, atau atas nama badan usaha, tuntutan pidana dan sanksi pidana dijatuhkan kepada: a). badan usaha; b). orang yang memberi perintah untuk melakukan tindak pidana tersebut atau orang yang bertindak sebagai pemimpin kegiatan dalam tindak pidana tersebut.

Kedua, Apabila tindak pidana lingkungan hidup sebagaimana dimaksud pada ayat (1) dilakukan oleh orang yang berdasarkan hubungan kerja atau berdasarkan hubungan lain yang bertindak dalam lingkup kerja badan usaha, sanksi pidana dijatuhkan terhadap pemberi perintah atau pemimpin dalam tindak pidana tersebut tanpa memperhatikan tindak pidana tersebut dilakukan secara sendiri atau bersama-sama.

Dalam konteks hukum pidana, penegakan hukum dapat diartikan sebagai suatu usaha untuk menanggulangi kejahatan secara rasional, memenuhi rasa keadilan, dan berdaya guna. Dalam rangka menanggulangi kejahatan terhadap berbagai sarana sebagai reaksi yang dapat diberikan kepada pelaku kejahatan, baik berupa sarana pidana maupun non hukum pidana, pada dasarnya dapat diintegrasikan satu dengan yang lainnya. Apabila sarana pidana dipanggil untuk menanggulangi kejahatan, berarti akan dilaksanakan politik hukum pidana, yakni mengadakan pemilihan untuk mencapai hasil perundang-undangan pidana yang sesuai dengan keadaan dan situasi pada suatu waktu dan untuk masa-masa yang akan datang.

Dalam teori identifikasi, korporasi dapat melakukan tindak pidana secara langsung melalui orang yang sangat berhubungan erat dengan korporasi dan dipandang sebagai korporasi itu sendiri. Perbuatan yang dilakukan oleh anggota-anggota tertentu dari korporasi, selama perbuatan itu untuk dan/atau atas nama korporasi, dianggap sebagai perbuatan dari korporasi itu sendiri, sehingga ketika perbuatan tersebut mengakibatkan terjadinya kerugian, atau dengan kata lain, jika anggota tersebut melakukan tindak pidana, sesungguhnya tindak pidana itu merupakan tindak pidana yang dilakukan oleh korporasi, sehingga korporasi juga bisa dimintai pertanggungjawaban atas tindak pidana yang dilakukan.

Dalam model pertanggungjawaban pidana korporasi, dikenal adanya pertanggungjawaban pengganti (vicarious liability), yaitu apabila korporasi melakukan tindak pidana maka penguruslah yang bertanggungjawab. Keberadaan pertanggungjawaban pengganti pada dasarnya adalah untuk menjawab pertanyaan apakah terhadap seseorang tersebut dapat dipertanggungjawabkan secara pidana atas tidak pidana yang dilakukan oleh orang lain. Dengan perkataan lain apakah perbuatan dan kesalahan seseorang 
itu bisa dimintakan pertanggungjawabannya kepada orang lain. Pertanyaan ini muncul karena pada dasarnya pertanggung jawaban merupakan hal pribadi. ${ }^{21}$

Pada awalnya pertanggungjawaban pidana korporasi berdasarkan teori pertanggungjawaban pengganti hanya akan bisa dimintakan apabila terjadi dua hal, dan bila tidak satupun tercakup didalamnya, maka korporasi dimaksud hanya bertanggungjawab secara perdata. Kedua hal tersebut adalah: ${ }^{22}$ pertama: Apabila tindak pidana yang dilakukan oleh seseorang itu adalah tindak pidana yang sama seperti dianjurkan oleh korporasi. kedua, Apabila tindak pidana yang dilakukan seseorang itu merupakan suatu tindak pidana yang lain dari yang dianjurkan, akan tetapi tindak pidana yang terjadi itu merupakan konsekwensi logis dari perbuatan yang dimintakan dilakukannya.

Pidana yang dapat dikenakan pada korporasi berdasarkan ketentuan pidana UU PPLH adalah pidana denda dan pidana tambahan atau tindakan tata tertib berupa perampasan keuntungan yang diperoleh dari tindak pidana, penutupan seluruh atau sebagian tempat usaha dan/atau kegiatan, perbaikan akibat tindak pidana, pewajiban mengerjakan apa yang dilalaikan tanpa hak, dan/atau penempatan perusahaan di bawah pengampuan paling lama 3 (tiga) tahun.

Beberapa ketentuan terkait pola pemidanaan yang berdasar pada konservasi lingkungan hidup, yaitu pemberatan pidana denda, pengaturan pelaksanaan pidana denda, dan tindakan pemulihan lingkungan hidup. Diantaranya:

Pertama, Pemberatan Pidana Denda. Pidana denda merupakan jenis pidana pokok yang ketiga di dalam hukum pidana Indonesia, yang pada dasarnya hanya dapat dijatuhkan bagi orang-orang dewasa. ${ }^{23}$ Pengenaan pidana denda tersebut diharapkan dapat mengurangi tindak pidana di bidang lingkungan hidup sehingga pidana denda yang dijatuhkan harus lebih besar dari keuntungan yang diperoleh pelaku dari hasil tindak pidana tersebut. Terkait hal ini, UU PPLH mengatur bahwa ancaman pidana denda bagi pelaku korporasi diperberat sepertiga. Ketentuan ini menjadikan tujuan pengenaan pidana denda tidak terwujud ketika keuntungan yang diperoleh oleh korporasi dari tindak pidana lingkungan hidup yang dilakukannya lebih besar dari

${ }^{21}$ Hasbullah f.sjawie,...., hlm. 28

${ }^{22}$ Hasbullah f.sjawie,...., hlm. 28

${ }^{23}$ P.A.F. Lamintang, Hukum Penitensier Indonesia, Armico, Bandung, Edisi Pertama, hlm. 80 
pidana denda yang dikenakan pada korporasi, mengingat ancaman maksimal pidana denda dalam UU PPLH hanya Rp 15 Miliar.

Kedua, Pengaturan Pelaksanaan Pidana Denda. Pidana denda yang diatur dalam undang-undang di bidang lingkungan hidup membutuhkan suatu aturan pelaksana agar tetap menjamin pelaksanaan konservasi lingkungan hidup oleh pelaku tindak pidana meskipun pidana denda tidak dapat dibayar oleh pelaku tindak pidana tersebut. Terkait hal ini, UUPPLH tidak mengatur ketentuan pelaksanaan pidana denda yang tidak dibayar oleh terpidana sehingga berlaku ketentuan umum sebagaimana diatur dalam Pasal 30 KUHP yang menyatakan bahwa jika pidana denda tidak dibayar maka diganti pidana kurungan dimana pidana kurungan tersebut tidak boleh lebih dari 8 (delapan) bulan. Ketentuan tersebut menyebabkan penjatuhan pidana denda menjadi tidak efektif.

Ketiga, Sanksi Tindakan Perbaikan Akibat Tindak Pidana Bersifat Imperatif. Hukum pidana dalam usahanya mencapai tujuan-tujuannya tidak semata-mata menjatuhkan pidana, tetapi juga ada kalanya menggunakan tindakan-tindakan. Tindakan adalah suatu sanksi juga, tetapi tidak ada sifat pembalasan padanya. Maksud tindakan adalah untuk menjaga keamanan masyarakat terhadap orang-orang yang banyak atau sedikit dipandang berbahaya, dan dikhawatirkan akan melakukan perbuatan-perbuatan pidana. ${ }^{24}$

Akibat hukum yang dapat dibebankan pada korporasi dalam melakukan tindak pidana lingkungan hidup diatur dalam Pasal 97 sampai Pasal 119 UUPPLH. Sedang dalam Pasal 97 berbunyi: Tindak pidana dalam undang-undang ini merupakan kejahatan.

Menurut Pasal 98 berbunyi: (1) Setiap orang yang dengan sengaja melakukan perbuatan yang mengakibatkan dilampauinya baku mutu udara ambien, baku mutu air, baku mutu air laut, atau kriteria baku kerusakan lingkungan hidup dipidana dengan pidana penjara paling singkat 3 (tiga) tahun dan paling lama 10 (sepuluh) tahun dan denda paling sedikit Rp3.000.000.000,00 (tiga miliar rupiah) dan paling banyak Rp10.000.000.000,00 (sepuluh miliar rupiah). (2) Apabila perbuatan sebagaimana dimaksud pada ayat (1) mengakibatkan orang luka dan/atau bahaya kesehatan manusia, dipidana dengan pidana penjara paling singkat 4 (empat) tahun dan paling lama 12 (dua belas) tahun dan denda paling sedikit Rp 4.000.000.000,00 (empat miliar rupiah) dan paling banyak Rp12.000.000.000,00 (dua belas miliar rupiah).

${ }^{24}$ Roeslan Saleh, Stelsel Pidana di Indonesia, Cetakan Kelima (Jakarta: Aksara Baru, 1987), hlm. 47 
(3) Apabila perbuatan sebagaimana dimaksud pada ayat (1) mengakibatkan orang luka berat atau mati, dipidana dengan pidana penjara paling singkat 5 (lima) tahun dan paling lama 15 (lima belas) tahun dan denda paling sedikit Rp5.000.000.000,00 (lima miliar rupiah) dan paling banyak Rp15.000.000.000,00 (lima belas miliar rupiah).

Menurut Pasal 99 berbunyi: (1) Setiap orang yang karena kelalaiannya mengakibatkan dilampauinya baku mutu udara ambien, baku mutu air, baku mutu air laut, atau kriteria baku kerusakan lingkungan hidup, dipidana dengan pidana penjara paling singkat 1 (satu) tahun dan paling lama 3 (tiga) tahun dan denda paling sedikit Rp1.000.000.000,00 (satu miliar rupiah) dan paling banyak Rp3.000.000.000,00 (tiga miliar rupiah). (2) Apabila perbuatan sebagaimana dimaksud pada ayat (1) mengakibatkan orang luka dan/atau bahaya kesehatan manusia, dipidana dengan pidana penjara paling singkat 2 (dua) tahun dan paling lama 6 (enam) tahun dan denda paling sedikit Rp2.000.000.000,00 (dua miliar rupiah) dan paling banyak Rp6.000.000.000,00 (enam miliar rupiah). (3) Apabila perbuatan sebagaimana dimaksud pada ayat (1) mengakibatkan orang luka berat atau mati, dipidana dengan pidana penjara paling singkat 3 (tiga) tahun dan paling lama 9 (sembilan) tahun dan denda paling sedikit Rp.3.000.000.000,00 (tiga miliar rupiah) dan paling banyak Rp.9.000.000.000,00 (sembilan miliar rupiah).

Menurut Pasal 100 berbunyi (1) Setiap orang yang melanggar baku mutu air limbah, baku mutu emisi, atau baku mutu gangguan dipidana dengan pidana penjara paling lama 3 (tiga) tahun dan denda paling banyak Rp.3.000.000.000,00 (tiga miliar rupiah). (2) Tindak pidana sebagaimana dimaksud pada ayat (1) hanya dapat dikenakan apabila sanksi administratif yang telah dijatuhkan tidak dipatuhi atau pelanggaran dilakukan lebih dari satu kali.

Menurut Pasal 101 berbunyi: Setiap orang yang melepaskan dan/atau mengedarkan produk rekayasa genetik ke media lingkungan hidup yang bertentangan dengan peraturan perundang-undangan atau izin lingkungan sebagaimana dimaksud dalam Pasal 69 ayat (1) huruf g dipidana dengan pidana penjara paling singkat 1 (satu) tahun dan paling lama 3 (tiga) tahun dan denda paling sedikit Rp1.000.000.000,00 (satu miliar rupiah) dan paling banyak Rp3.000.000.000,00 (tiga miliar rupiah).

Menurut Pasal 102 berbunyi: Setiap orang yang melakukan pengelolaan limbah B3 tanpa izin sebagaimana dimaksud dalam Pasal 59 ayat (4) dipidana dengan pidana penjara paling singkat 1 (satu) tahun dan paling lama 3 (tiga) 
tahun dan denda paling sedikit Rp1.000.000.000,00 (satu miliar rupiah) dan paling banyak Rp3.000.000.000,00 (tiga miliar rupiah).

Menurut Pasal 103 berbunyi: Setiap orang yang menghasilkan limbah B3 dan tidak melakukan pengelolaan sebagaimana dimaksud dalam Pasal 59 dipidana dengan pidana penjara paling singkat 1 (satu) tahun dan paling lama 3 (tiga) tahun dan denda paling sedikit Rp1.000.000.000,00 (satu miliar rupiah) dan paling banyak Rp3.000.000.000,00 (tiga miliar rupiah).

Menurut Pasal 104 berbunyi: Setiap orang yang melakukan dumping limbah dan/atau bahan ke media lingkungan hidup tanpa izin sebagaimana dimaksud dalam Pasal 60 dipidana dengan pidana penjara paling lama 3 (tiga) tahun dan denda paling banyak Rp3.000.000.000,00 (tiga miliar rupiah).

Menurut Pasal 105 berbunyi: Setiap orang yang memasukkan limbah ke dalam wilayah Negara Kesatuan Republik Indonesia sebagaimana dimaksud dalam Pasal 69 ayat (1) huruf $\mathrm{c}$ dipidana dengan pidana penjara paling singkat 4 (empat) tahun dan paling lama 12 (dua belas) tahun dan denda paling sedikit Rp4.000.000.000,00 (empat miliar rupiah) dan paling banyak Rp12.000.000.000,00 (dua belas miliar rupiah).

Menurut Pasal 106 berbunyi: Setiap orang yang memasukkan limbah B3 ke dalam wilayah Negara Kesatuan Republik Indonesia sebagaimana dimaksud dalam Pasal 69 ayat (1) huruf d dipidana dengan pidana penjara paling singkat 5 (lima) tahun dan paling lama 15 (lima belas) tahun dan denda paling sedikit Rp5.000.000.000,00 (lima miliar rupiah) dan paling banyak Rp15.000.000.000,00 (lima belas miliar rupiah).

Menurut Pasal 107 berbunyi: Setiap orang yang memasukkan B3 yang dilarang menurut peraturan perundang-undangan ke dalam wilayah Negara Kesatuan Republik Indonesia sebagaimana dimaksud dalam Pasal 69 ayat (1) huruf $\mathrm{b}$ dipidana dengan pidana penjara paling singkat 5 (lima) tahun dan paling lama 15 (lima belas) tahun dan denda paling sedikit Rp5.000.000.000,00 (lima miliar rupiah) dan paling banyak Rp15.000.000.000,00 (lima belas miliar rupiah).

Menurut Pasal 108 berbunyi: Setiap orang yang melakukan pembakaran lahan sebagaimana dimaksud dalam Pasal 69 ayat (1) huruf $\mathrm{h}$ dipidana dengan pidana penjara paling singkat 3 (tiga) tahun dan paling lama 10 (sepuluh) tahun dan denda paling sedikit Rp3.000.000.000,00 (tiga miliar rupiah) dan paling banyak Rp10.000.000.000,00 (sepuluh miliar rupiah). 
Menurut Pasal 109 berbunyi: Setiap orang yang melakukan usaha dan/atau kegiatan tanpa memiliki izin lingkungan sebagaimana dimaksud dalam Pasal 36 ayat (1) dipidana dengan pidana penjara paling singkat 1 (satu) tahun dan paling lama 3 (tiga) tahun dan denda paling sedikit Rp1.000.000.000,00 (satu miliar rupiah) dan paling banyak Rp3.000.000.000,00 (tiga miliar rupiah).

Menurut Pasal 110 berbunyi: Setiap orang yang menyusun amdal tanpa memiliki sertifikat kompetensi penyusun amdal sebagaimana dimaksud dalam Pasal 69 ayat (1) huruf i dipidana dengan pidana penjara paling lama 3 (tiga) tahun dan denda paling banyak Rp3.000.000.000,00 (tiga miliar rupiah).

Menurut Pasal 111 berbunyi: (1) Pejabat pemberi izin lingkungan yang menerbitkan izin lingkungan tanpa dilengkapi dengan amdal atau UKL-UPL sebagaimana dimaksud dalam Pasal 37 ayat (1) dipidana dengan pidana penjara paling lama 3 (tiga) tahun dan denda paling banyak Rp3.000.000.000,00 (tiga miliar rupiah). (2) Pejabat pemberi izin usaha dan/atau kegiatan yang menerbitkan izin usaha dan/atau kegiatan tanpa dilengkapi dengan izin lingkungan sebagaimana dimaksud dalam Pasal 40 ayat (1) dipidana dengan pidana penjara paling lama 3 (tiga) tahun dan denda paling banyak Rp3.000.000.000,00 (tiga miliar rupiah).

Menurut Pasal 112 berbunyi: Setiap pejabat berwenang yang dengan sengaja tidak melakukan pengawasan terhadap ketaatan penanggung jawab usaha dan/atau kegiatan terhadap peraturan perundang-undangan dan izin lingkungan sebagaimana dimaksud dalam Pasal 71 dan Pasal 72, yang mengakibatkan terjadinya pencemaran dan/atau kerusakan lingkungan yang mengakibatkan hilangnya nyawa manusia, dipidana dengan pidana penjara paling lama 1 (satu) tahun atau denda paling banyak Rp500.000.000,00 (lima ratus juta rupiah).

Menurut Pasal 113 berbunyi: Setiap orang yang memberikan informasi palsu, menyesatkan, menghilangkan informasi, merusak informasi, atau memberikan keterangan yang tidak benar yang diperlukan dalam kaitannya dengan pengawasan dan penegakan hukum yang berkaitan dengan perlindungan dan pengelolaan lingkungan hidup sebagaimana dimaksud dalam Pasal 69 ayat (1) huruf j dipidana dengan pidana penjara paling lama 1 (satu) tahun dan denda paling banyak Rp1.000.000.000,00 (satu miliar rupiah).

Menurut Pasal 114 berbunyi: Setiap penanggung jawab usaha dan/atau kegiatan yang tidak melaksanakan paksaan pemerintah dipidana dengan 
pidana penjara paling lama 1 (satu) tahun dan denda paling banyak Rp1.000.000.000,00 (satu miliar rupiah).

\section{KESIMPULAN}

Pencemaran lingkungan terjadi apabila daur materi dalam lingkungan hidup mengalami perubahan sehingga keseimbangan dalam hal struktur dan fungsinya terganggu. Salah satu kewajiban dari sebuah perusahaan adalah menjaga lingkungan hidup. Permasalahan yang timbul dari tindak pidana Dumping Limbah B3 pembuangan Limbah B3 adalah tidak dilakukannya pengelolaan Limbah B3.

Lingkungan hidup dengan segala komponen yang ada di dalamnya sangat dibutuhkan dalam pertumbuhan dan perkembangan hidup manusia. Dalam KUHP saat ini yang berlaku di Indonesia tidak dikenal adanya satu ketentuan pun yang menetapkan korporasi sebagai subyek delik dalam hukum pidana. Dalam hal pengurus korporasi sebagai pembuat dan pengurus yang bertanggungjawab, kepada pengurus korporasi dibebankan kewajibankewajiban tertentu.

\section{REFERENSI:}

Absori, Penegakan Hukum Lingkungan pada Era Reformasi, Jurnal Ilmu Hukum, Vol.8, No.2, September 2005, h. 221-237

Ali, Zainuddin. Metode Penelitian Hukum, Sinar Grafika, Jakarta, 2009.

Hasbullah F. Sjawie, Pertanggungjawaban Pidana Korporasi pada Tindak pidana Korupsi, Prenada Media Group, Jakarta, 2015.

Kansil, CST; dan Christine Kansil., Pokok-pokok Hukum Pidana, Pradnya Paramita, 2004

Manan, Abdul. 2015, Pencemaran Dan Perusakan Lingkungan Dalam Perspektif Hukum Islam, Jurnal Hukum dan Peradilan, Vol. 4, No. 2, hlm. 228.

Marzuki, Peter Mahmud. Penelitian Hukum, Kencana Prenada Media Group, Jakarta, 2010

Mukri, S.G.; Aji, A.M.; Yunus, N.R. (2016). "Implementation of Religious Education in the Constitution of the Republic of Indonesia," Salam: Sosial dan Budaya Syar-i, Volume 3 No. 3. 
Mukri, S.G.; Aji, A.M.; Yunus, N.R. (2017). Relation of Religion, Economy, and Constitution In The Structure of State Life, STAATSRECHT: Indonesian Constitutional Law Journal, Volume 1, No. 1.

Muladi; \& Dwidja Priyanto, Pertanggungjawaban Pidana Korporasi. Kencana Prenada Media Group, Jakarta, 2010.

N.H.T. Siahaan, Hukum lingkungan dan Ekologi Pembangunan, edisi kedua, Penerbit Erlangga, Jakarta, 2004

P.A.F. Lamintang, Hukum Penitensier Indonesia, Armico, Bandung, Edisi Pertama, hlm. 80

Pakpahan, Rudy Hendra. Pertanggungjawaban Pidana Korporasi Perkebunan Atas Pencemaran Limbah Kelapa Sawit., Jurnal Legislasi Indonesia Vol 17 No. 2 Juni 2020 : 223-233

Raksodipoetra, Marjono. Kejahatan Korporasi dan Pertanggungjawabannya, Universitas Gadjah Mada, Yogyakarta, 2014.

Saleh, Roeslan. Stelsel Pidana di Indonesia, Cetakan Kelima (Jakarta: Aksara Baru, 1987).

Setiyono, Kejahatan Korporasi Analisis Viktimiologis dan Pertanggungjawaban Korporasi dalam Hukum Pidana Indonesia, Bayumedia Publishing, Malang, 2009.

Silalahi, M. Daud. Hukum Lingkungan dalam Sistem Penegakan Hukum Lingkungan Indonesia, Alumni, Bandung, 2001

Simpon, Selly S. Corporate Crime, Law and Social Control. Cambridge University Pers, London, 2002.

Subagyo, P. Joko. Hukum Lingkungan dan Masalah Penanggulannnya, Edisi Terbaru, Rineka Cipta, Jakarta, 1999.

Sunarso, Siswanto. Hukum Pidana Lingkungan Hidup dan Strategi Penyelesaian Sengketa, Jakarta: Rineka Cipta, 2005.

Thomas, William Robert. How And Why Should The Criminal Law Punish Corporation, Dissertation, University of Michigan, 2015

Undang-Undang Nomor 32 Tahun 2009 tentang Perlindungan dan Pengelolaan lingkungan Hidup

UU No. 32 Tahun 2009 tentang PPLH 
Yunus, N.R.; Anggraeni, RR Dewi.; Rezki, Annissa. (2019). "The Application of Legal Policy Theory and its relationship with Rechtsidee Theory to realize Welfare State," 'Adalah, Volume 3, No. 1. 